University of Warwick institutional repository: http://go.warwick.ac.uk/wrap This paper is made available online in accordance with publisher policies. Please scroll down to view the document itself. Please refer to the repository record for this item and our policy information available from the repository home page for further information.

To see the final version of this paper please visit the publisher's website. Access to the published version may require a subscription.

\author{
Author(s): TESSA ROYNON \\ Classics \\ Year of publication: 2007 \\ Link to published version: http://dx.doi.org/ \\ $10.1017 /$ S0021875806002738 \\ Publisher statement: None
}

Article Title: A New "Romen" Empire: Toni Morrison's Love and the 
Journal of American Studies, 4I (2007), I, 3 I-47 C 2006 Cambridge University Press doi:10.1017/So021875806002738 Printed in the United Kingdom

\title{
A New "Romen" Empire: Toni Morrison's Love and the Classics
}

\author{
TESSA ROYNON
}

An important but little-studied feature of Toni Morrison's novels is their ambivalent relationship with classical tradition. Morrison was a classics minor while at Howard University, and her deployment of the cultural practices of ancient Greece and Rome is fundamental to her radical project. Indeed, the works' revisionary classicism extends far beyond the scope of established criticism, which has largely confined itself to the engagement with Greek tragedy in Beloved, with the Demeter/Kore myth in The Bluest Eye and with allusions to Oedipus and Odysseus in Song of Solomon. ${ }^{\mathbf{1}}$ Morrison

Tessa Roynon has recently submitted her doctoral thesis on Toni Morrison and classical tradition in the Department of English at the University of Warwick. She can be contacted at tessa_roynon@hotmail.com.

My thanks to Helen M. Dennis and Marc Conner for their encouragement of this project, and to Elizabeth Barry for her invaluable advice. The research which gave rise to this article was funded by an AHRC postgraduate award.

${ }^{1}$ Earlier versions of this paper were presented at the BAAS Conference in Manchester, April 2004 and the Toni Morrison Society Conference in Cincinnati, Ohio, July 2005. The article is adapted from my longer work, Transforming America: Toni Morrison and Classical Tradition (in progress). No published full-length study of this subject currently exists. Extant single essays on the classical allusiveness in individual novels include (on The Bluest Eye) Stephanie

A. Demetrakopoulos, "Bleak Beginnings," in Stephanie A Demetrakopoulos and Karla F. C. Holloway, New Dimensions of Spirituality: A Biracial and Bicultural Reading of the Novels of Toni Morrison (New York: Greenwood Press, 1987), 3 I-36; Madonne M. Miner, "Lady No Longer Sings the Blues: Rape, Madness, and Silence in The Bluest Eye," in Harold Bloom, ed., Modern Critical Views: Toni Morrison (New York and Philadelphia: Chelsea House Publishers, I 990) 85-99; (on Song of Solomon) Kimberly W. Benston, "Re-weaving the 'Ulysses Scene': Enchantment, Post-Oedipal Identity and the Buried Text of Blackness in Song of Solomon," in Hortense Spillers, ed., Comparative American Identities: Race, Sex and Nationality in the Modern Text (New York: Routledge, I99I) 87-109; William K. Freiert, "Classical Themes in Toni Morrison's Song of Solomon," Helios, io (1988), I6 I-70; Trudier Harris, "Milkman Dead: An Anti-classical Hero," in idem, Fiction and Folklore: The Novels of Toni Morrison (Knoxville, TN: University of Tennessee Press, I991), 85-94; Bessie W. Jones, "Greek Tragic Motifs in Song of Solomon," in Bessie W. Jones and Audrey L. Vinson, eds., The World of Toni Morrison: Explorations in Literary Criticism (Dubuqe, IA: Kendall Hunt Publishing Company, 1985), 103-14; and (on Beloved) Lillian Corti, "Medea and Beloved: Self-Definition and Abortive Nurturing in Literary Treatments of the Infanticidal Mother," in Lilian A. R. Furst and Peter W. Graham, eds., Disorderly Eaters: Texts in 
repeatedly subverts the central role that Greece and Rome have played in American self-definition and historiography. In Paradise, for example, the affinity between the Oven in Ruby and the Greek koine hestia or communal hearth critiques the historical Founding Fathers' insistence on their new nation's analogical relationship with the ancient republics. And in their densely allusive rewritings of slavery, the Civil War and its aftermath, Beloved and Jazz expose the dependence of the "Old South" on classical pastoral tradition. It should come as no surprise, therefore, that in her most recent novel - Love (2003) - Morrison further develops the transformative engagement with America's Graeco-Roman inheritance that characterizes all of her previous fiction. $^{2}$

In the two years since its publication, the new novel has provoked mixed reactions amongst both journalists and scholars. ${ }^{3}$ Perhaps this is because appearing after the magnificent trilogy that so explicitly takes on all the grand themes of African American history - Love confounds readers' expectations of what a book by this author should be and should do. Only just two hundred pages long, and with a plot centred on a feud between two old women in a decayed mid-Atlantic resort town, the work initially impresses as an authorial turning-away from previous profound concerns, or even as a

Self-Empowerment (University Park, PA: Pennsylvania State University Press, I992), 6I-77; Shelley P. Haley, "Self-Definition, Community and Resistance: Euripides' Medea and Toni Morrison's Beloved," Thamyris, 2, 2 (Autumn i 995), I77-206; Samuel A. Kimball, "Genesis, Oedipus and Infanticidal Abjection in Toni Morrison's Beloved," Literature and Psychology, 43, 3 (1997), 4I-65; Carl Malmgrem, "Mixed Genres and the Logic of Slavery," Critique: Studies in Contemporary Fiction, 36, 2 (1995), 96-106; Terry Otten, "Transfiguring the Narrative: Beloved from Melodrama to Tragedy," in Barbara Solomon, ed., Critical Essays on Toni Morrison's Beloved (Boston and New York: G. K. Hall, I998), 284-99; Carol Schmudde, "Knowing When To Stop': A Reading of Toni Morrison's Beloved," CLA Journal, 37, 2 (Dec. I 993), I 2 I-35.

2 The author herself has frequently drawn attention to her interest in the classics. For example, when asked whether she sees "any relationship between between Greek tragedy and the Black experience," she replies, "Well, I do. I ... thought it was just because I was a classics minor that it was important to me. But there was something about the Greek chorus ... that reminds me of what goes on in Black churches and in jazz ..." Bessie W. Jones and Audrey Vinson, “An Interview with Toni Morrison” (1985) in Danille TaylorGuthrie, ed., Conversations with Toni Morrison (Jackson, MS: University Press of Mississippi, I994), I 7 I -87 .

${ }^{3}$ For examples of unfavourable reviews of Love in the mainstream media see Alex Clark, "Review: Fiction: Love by Toni Morrison," Sunday Times, 9 Nov. 2003, 34; Michiko Kakutani, "Family Secrets, Feuding Women," New York. Times, 31 Oct. 2003, 37; Laura Miller, "The Last Resort," New York Times, 2 Nov. 2003, Io; and Jonathan Yardley, "'Love' by Toni Morrison," Washington Post, 26 Oct. 2003, BWo2. The novel was the focus of a panel-led discussion at the ALA conference in San Francisco, May 2004, and received considerable attention at the Toni Morrison Society Conference in Cincinnati, July 2005. 
self-indulgence born of established success. But, as I shall go on to demonstrate, its apparently diminished scale is in fact something of an illusion. Close analysis of its allusiveness, both to classical tradition (in particular to the legend of Lucretia and the myth of Kore) and to dominant American culture's strategic use of that tradition, reveals that Love extends the thematic interests of Tar Baby: it sets out to demythologize and reconfigure nothing less than the history of the country's "discovery" and colonization.

The novel is structured around acts of rape and is unified by anxiety about rape. In the early pages we encounter the young protagonist (none-too-subtly named "Romen") refusing to join in with his friends" horrific gang-rape of a girl at a party. Later we find out that the administrator of June's correctional molested her, while the collapse of Christine's relationship with a civil-rights agitator, Fruit, was precipitated by his failure to react appropriately when "somebody raped one of the student volunteers." And we eventually discover that the all-powerful hotel owner, Bill Cosey, married his second wife, Heed, when she was just eleven years of age. Cosey is an obvious embodiment of the American dream, and given the fact that he creates a "fabulous, successful resort" described as a "paradise" and as a "fairytale that lived on even after the hotel was dependent for its life on the people it once excluded," it is not hard to read the man as an allegorical representation of America itself. ${ }^{5}$ Through his creation of an empire on the very coast explored by Ponce de León and De Soto, and where Walter Raleigh and John Smith founded their settlements, Morrison invokes the European conquest of that region. And the character's relationship with the child bride Heed, which reverberates in the story's other acts of sexual exploitation, is clearly a parodic version of the configuration of America as the innocent virgin despoiled by the allconquering hero. The author thus destabilizes the narrative of American settlement as a kind of glorious sexual assault - a narrative itself informed by classical tradition - that is something of a refrain in the national literature.

Morrison's engagement with ancient Rome in this novel is not restricted to allusions to its tales of rape or to the Latin works that were used to justify and dignify the colonization process. The novel is suffused with a general "Romanness": streets in the town of Silk have "epic movie names," including one called "Gladiator," while the fact that Romen is known by his family's name ("the Gibbons boy") connotes Edward Gibbon's Decline and Fall of the Roman Empire. ${ }^{6}$ Through such details Morrison exploits the ironic potential

4 Toni Morrison, Love (London: Chatto and Windus 2003), I78. $\quad{ }^{5}$ Ibid., 42.

${ }^{6}$ Ibid., 40, 86, 24. We can assume from the account of Soaphead Church's reading in The Bluest Eye that Morrison has read Gibbon: Soaphead “noticed Gibbon's acidity, but not his tolerance"; Toni Morrison, The Bluest Eye (London: Picador, I971 ; first published 1970), 
inherent in what William Vance - in his America's Rome - calls “Rome's apparently inexhaustible capacity to contribute to America's unending process of self-definition." The description of Bill Cosey as "the Big Man who, with no one to stop him, could get away with ... anything ... he wanted" partakes in the unflattering affinity between contemporary America and a corrupt, precarious imperial Rome that has something of an intellectual tradition of its own. ${ }^{8}$ It develops the parallel intimated in Tar Baby, where the colonialist Valerian (with his "head-of-a-coin-profile") proudly tells Son, "I was named after an emperor." In addition, the fact that the overbearing portrait of the resort founder recalls the veristic style of Roman portraiture - "it was painted from a snapshot, so it's exactly like him," says Heed - mocks the political deployment of neoclassical-style portraiture and statuary to which America's Founding Fathers were particularly prone. ${ }^{10}$ But the focus of this article corresponds to Morrison's central concern in the novel: the role of the classics in the construction of America's prevailing myths of origin and creation.

\section{AMERICA AS LUCRETIA}

Cosey's marriage to Heed is an exaggerated (and racially transposed) version of Valerian's union with Margaret in Tar Baby. Margaret, though describing herself as a "child bride," is at seventeen some six years older on her

I 34. There is a second, heavily veiled allusion to the collapse of Rome in Love: former guests at Cosey's hotel include two actresses, "one of whom had auditioned for Anna Lucasta,"the play by Philip Yordan; Morrison, Love, 75. Among the films for which Yordan went on to be screenwriter/co-producer was the famous epic Fall of the Roman Empire (1964).

7 William Vance, America's Rome (Yale and London: Yale University Press, i 989), xxix.

${ }^{8}$ Morrison, Love, I 33. Peter Stothard sums up this intellectual tradition in his review of Tom Holland's recently published Rubicon: The Triumph and Tragedy of the Roman Republic (London: Little, Brown, 2003). Stothard writes that the author's "notion of Americans as neo-Romans is not an original idea and has been much bandied about by foreign policy watchers since the end of the Cold War. ... Holland's narrative of the first century before Christ is well crafted for those with current Americans on their mind"; Peter Stothard, "From Capitol to Capitol," Times Literary Supplement, 3 Oct. 2003, 6.

9 Toni Morrison, Tar Baby (London: Picador, I 991 ; first published 1981), 203, I 47.

${ }^{10}$ Morrison, Love, 26. According to the Oxford Classical Dictionary, Roman portraiture is "especially noted for its verism, the meticulous recording of facial characteristics including such unflattering features as wrinkles, warts and moles"; Oxford Classical Dictionary, $3 \mathrm{rd}$ edn rev. (Oxford: Oxford University Press, 2003), i 229. For analysis of the political function of portraiture and statuary in the early American Republic see Clive Bush, "The Hero as Representative," in idem, The Dream of Reason: American Consciousness and Cultural Achievement from Independence to the Civil War (London: Edward Arnold, 1977), 19-57, and Gary Wills, "Fame," in idem, Cincinnatus: George Washington and the American Enlightenment (Garden City, New York: Doubleday, i 984), 109-32. 
wedding day than is Cosey's wife on hers. ${ }^{\mathbf{1 1}}$ Both girls are implicitly associated with the phenomenon that is the American land: Margaret first catches Valerian's eye when marketed in a parade as "the Principal Beauty of Maine,"12 while Heed grows up in a neighbourhood significantly named "the Settlement."13 The Roman-named, island-conquering Valerian, the empirebuilding Cosey and the sexually voracious Romen are all implicated in Morrison's reassessment of what the critic Eleanor Traylor (in her description of Tar Baby's Isle des Chevaliers) calls "a virgin world raped by the machinations of man."

Numerous scholars have documented the dominant cultural convention of representing America's discovery as a sexual conquest; many also share Morrison's interest in the widespread deployment of classical tradition in these representations. To start with the best-known, in The Lay of the Land Annette Kolodny infers from her analyses of discovery narratives that "the single dominating metaphor" of "the land as woman" comprises both "the regressive pull of maternal containment" and "the seductive invitation to sexual assertion."15 Meanwhile, Louise Westling's The Green Breast of the New World adopts a more ecocritical approach to what she calls "the strange combination of eroticism and misogyny" that characterizes narratives of America's creation. ${ }^{\mathbf{1 6}}$ While neither woman focusses primarily on the influence of the classics, both do discuss the role of the pastoral tradition in shaping attitudes to the colonizing process. In addition, although not particularly concerned by the gender politics of their subject matter, Martin Snyder's I976 essay "The Hero in the Garden: Classical Contributions to the Early Images of America"17 and John Shields's more recent American Aeneas provide detailed discussion of the engagement with Virgilian and Ovidian

11 Morrison, Tar Baby, 23.

12 Ibid., I4.

13 Morrison, Love, 53.

${ }^{14}$ Eleanor Traylor, "The Fabulous World of Toni Morrison: Tar Baby," in Nellie McKay, ed., Critical Essays on Toni Morrison (Boston: G. K. Hall, I988), I 35-49, I 38 . Traylor's essay is important because it expounds the various classical connotations of the name "Valerian." "A farmer," Valerian "was Roman emperor from A.D. 253-260"; the name "derives from the Latin proper noun Valerius, the name of a Roman clan"; and a related verb is valeo, which can mean both "to be strong" and "to bid farewell"; ibid., I 38. But Traylor neither asserts nor analyses the important connection between Valerian's associations with ancient Rome and his colonialist act of buying and settling "an island in the Caribbean for almost nothing"; Morrison, Tar Baby, 50.

15 Annette Kolodny, The Lay of the Land: Metaphor as Experience and History in American Life and Letters (Chapel Hill: University of North Carolina Press, I 975), 6, 67.

${ }^{16}$ Louise H. Westling, The Green Breast of the New World: Landscape, Gender, and American Fiction (Athens, GA and London: University of Georgia Press, I996), 5.

17 Martin D. Snyder, "The Hero in the Garden: Classical Contributions to the Early Images of America," in John W. Eadie, ed., Classical Traditions in Early America (Ann Arbor, MI: Center for Co-ordination of Ancient and Modern Studies, I976), I 39-69. 
representations of the Golden Age that typified the "New World promotional literature."18 Morrison's Love, however, draws attention to the symbiosis between classically-influenced and gendered representations of the conquest of America with a far greater urgency than does this scholarship which precedes it.

While the male critics conduct little analysis of what Nina Baym has famously called "the sexual definition" of American experience, it is perhaps more surprising that Kolodny's and Westling's studies do not address more directly the specific configuration of colonization as rape. ${ }^{\mathbf{1 9}}$ Kolodny does observe at the outset that early explorers repeatedly described the "maydenhead" or "Virgin Beauties" of the "new" continent, and ends with the warning that "we can no longer afford to keep turning "America the Beautiful' into 'America the Raped'." 20 But neither she nor Westling make any mention of works such as William Carlos Williams's In the American Grain (1925), ${ }^{21}$ to which notions of America's discovery as a heroic rape are pivotal, or of Vladimir Nabokov's Lolita (I95 5), ${ }^{22}$ which parodies the same paradigm. By contrast, in redirecting our attention to the centrality of rape in conceptions of America's beginnings, Morrison creates new perspectives on the literary and critical traditions that precede her. As I shall go on to demonstrate, her new novel can be read as a specific rebuke to the versions of American history and identity that Williams constructs. Thus the "classics" to which the subtitle of this article refers are not just those of

18 John C. Shields, American Aeneas: Classical Origins of the American Self (Knoxville, TN: University of Tennessee Press, 2001), 26. See Kolodny, 4-22, for her discussion of the role of pastoralism in colonization. She writes that "a uniquely American pastoral vocabulary" involves a "yearning to know and to respond to the landscape as feminine." Westling observes (with some tautology) that "When the Europeans first encountered the immense new continents of North and South America, they naturally projected familiar expectations upon what they saw before them: mythical conceptions of the Golden World from Hesiod, Edenic visions from Judeo-Christian culture, pastoral expectations from the Classics"; Westling, 33. On the echoes of depictions of the Golden Age in Ovid's Metamorphoses and Virgil's Eclogues in accounts of the New World, Martin Snyder quotes, for example, Peter Martyr's description of the inhabitants of the New World (on whom he himself never set eyes): "they seeme to live in that golden worlde of which olde writers speake so much"; Snyder, I5I. For Shields's discussion of the classicism of the discovery narratives see American Aeneas, 3-8.

19 Nina Baym, "Melodramas of Beset Manhood: How Theories of American Fiction Exclude Women Authors" (1981), reptd. in Lucy Maddox, ed., Locating American Studies: The Evolution of a Discipline (Baltimore: Johns Hopkins University Press, I999), 2 I 5-34.

${ }^{20}$ Kolodny, I 2, I 48; italics in original.

21 William Carlos Williams, In the American Grain (New York: New Directions, 1956; first published i 925 ).

22 Vladimir Nabokov, Lolita (New York: Vintage, i 997 ; first published i 955 ). 
Greece and Rome, but also those canonical American works which Love undermines.

In a recent interview on BBC Radio 4's Start the Week, Morrison stated that the image of the violated Pretty-Fay was her starting point in the creation of the novel. ${ }^{23}$ In the same programme, she made an observation about conventional literary treatments of rape that gives crucial weight to my argument about her concern with classicism. In response to a question about Cholly's assault on Pecola in The Bluest Eye, she said,

I've read rape scenes all my life - but they always seemed to have no shame. ... There was this male pride attached to it, in the language. [My writing] took it out of the realm of the fake, sensational romanticism in which rape is always played. We all say 'Oh my God, rape,' but when you look at the language, it's the language of pride. There is something about it, from the rape of Lucretia all the way on - so I just wanted to sabotage all of that. ${ }^{24}$

Given the thematic connections between The Bluest Eye and Love, and the fact that most of the radio programme was devoted to a discussion of the latter, I think it is fair to assume that in these words Morrison had her last novel in mind as well as the first. My question is, why does she make specific mention of the Lucretia legend here? If she wanted an example of the oldest or earliest act of rape in classical tradition, she would surely have mined Greek instead of Roman tradition. Instead, she cites the quasi-historical story of the rape committed by the son of the last king of Rome. My conviction is that her allusion to the Lucretia story sheds important light on Love's exploration of the multiple roles played by classicism in the colonization of America. To bear in mind the author's interest in that legend is to see that her description of her young protagonist on the verge of participating in the gang-rape connotes not just a classic conquistador but also a Tarquin: "his belt unbuckled, anticipation ripe, he was about to become the Romen he'd always known he was: chiseled, dangerous, loose."25

In The Rapes of Lucretia: A Myth and Its Transformations, Ian Donaldson elucidates the various associations between the Lucretia story and Roman

${ }^{23}$ Start the Week, BBC Radio 4, 8 Dec. 2003, available at http:/www.bbc.co.uk/radio4/ factual/starttheweek_2003I 208.shtml. Last accessed 28 Jan. 2004. In this interview Morrison said (of her creative process), "the little white-mitten hands in Love - that was the first thing I saw." It is essential to state at this point that in exploring the symbolic meanings of the rapes in Love I am not implying that they are not important or meaningful on a literal level. Morrison is of course concerned with the politics of actual rape; to suggest that her accounts are merely allusions or allegories would in fact be to replicate the misogynist practices of the very writers whom she seeks to counter. $\quad{ }^{24}$ Ibid.

25 Morrison, Love, 46. 
politics. ${ }^{26}$ The assaulted noblewoman functions on one level as a symbol of an annexed territory: she is "the figure of violated Rome," and "the rape epitomizes the wider tyranny of the Tarquins." 27 "If Rome is like Lucretia, Lucretia is also like Rome and her neighbouring cities," Donaldson continues. "Tarquin lays siege to her in much the same spirit as he besieges Ardea." 28 Thus there exists a compelling analogy between Lucretia's symbolic role and the conception of America as a despoiled young girl that Morrison parodies through Heed and the gruesomely assaulted Pretty-Fay.

There is also a literary precedent for the association of Lucretia with American colonization. Donaldson observes that the "correspondences" between Tarquin's rape and his family's aggressive foreign policies "become particularly prominent in Shakespeare's version of the story," and he quotes the Elizabethan's description of the victim's naked body: "Her breasts, like ivory globes circled with blue, / A pair of maiden worlds unconquered."29 The scholar does not suggest that Shakespeare is comparing Lucretia specifically to the "maiden world" of sixteenth-century America, but given the excitement surrounding the settlement of the new continent at the time of Shakespeare's writing, such an interpretation seems justified. In turn, Morrison's association between Romen and Tarquin - together with the implied affinities between Pretty-Fay, Heed, Lucretia and the American continent-exemplifies the palimpsest-like writing that is a feature of all her novels. It is this that enables her simultaneously to disrupt both the dominant myths of America's past and the ways in which those myths are constructed.

\section{THE PRECEDENT OF TAR BABY: COLONIZATION AS METAMORPHOSIS}

Morrison claims that her writing "took [rape] out of the fake, sensational romanticism in which [it] is always played." ${ }^{30}$ Analysis of Love reveals a

${ }^{26}$ Ian Donaldson, The Rapes of Lucretia: A Myth and Its Transformations (Oxford: Clarendon Press, 1982). Regrettably for my project, for the most part Donaldson limits his study of the recurring representations of the Lucretia myth to European literature and culture. The only consideration he gives to the story's significance in America concerns that country's interest in the role played by Lucius Junius Brutus in bringing about the Roman Republic following Tarquin's rape; Donaldson, I03-18. According to Donaldson, this "Brutus the First," as the playwright Vittorio Alfieri named him, was almost as popular with Revolutionary Americans as was the Republican martyr Cato. Alfieri dedicated his play Bruto Primo to George Washington in 1789 . Donaldson, I09. $\quad{ }^{27}$ Ibid., 9.

${ }^{28}$ Ibid., 9. $\quad{ }^{29}$ Ibid., 9, I7. $\quad{ }^{30}$ Start the Week, BBC Radio 4, 8 Dec. 2003. 
corresponding interest in taking accounts of the colonization of the Americas out of the fake romantic pastoralism in which it is so often played. While Todorov observes that the chivalric romances were "the conquistadors' favourite reading," 31 and Slotkin notes that Dryden's plays about the conquest of Mexico combine "the terms and conventions of Augustan tragic drama" with those of "the chivalric romance and the arcadian myth,"32 Morrison has Heed observe of her father's attitude to her marriage to Cosey, "Daddy knew a true romance when he saw it." "33 Given that L informs us that the girl's parents were glad to be rid of her, "for who knew how much money changed hands," Heed's version of events stands as an ironic exposure of the insidious capacity of "romance" to disguise both individual and historical realities. ${ }^{34}$ Morrison's scepticism again recalls Tar Baby, in which she portrays Valerian's posed pastoralism in an unsympathetic light. Having devastated the natural surroundings in order to "civilize" the island and build his mansion, the industrialist spends his time in his greenhouse, where he painstakingly cultivates hydrangeas and "Magnum Rex peonies." $\mathbf{3 5}$ Through this character whose imperial namesake was a farmer (as Traylor points out), ${ }^{36}$ the author satirizes the tradition of engaging classical pastoralism to dignify a process involving indiscriminate destruction of the natural world.

The canonical texts associated with the colony at Jamestown, Virginia comprise an especially striking example of settlers and historians deploying the classics to glorify the act of transforming the wilderness into settled territory. "The Agricola of Tacitus stands behind the encomium upon Captain John Smith entitled The Proceedings of the English Colonie in Virginia (I6r2)," observes M. E. Bradford, ${ }^{37}$ while Shields notes that Smith, describing his own project in his Generall Historie of Virginia (1624), writes that "he Vulcan like did forge a true plantation." 38 And given that there exists throughout Morrison's novels a critical engagement with Ovid's Metamorphoses, it is of particular relevance to this study that George Sandys translated the Roman poem "during the time that he served as treasurer to

31 Tzvetan Todorov, The Conquest of America: The Question of the Other, trans. Richard Howard (New York: Harper and Row, i 984), i 29.

32 Richard Slotkin, Regeneration through Violence: The Mythology of the American Frontier, I600-1860 (New York: HarperCollins, i 996; first published i973), 239. ${ }^{33}$ Morrison, Love, 62.

34 Ibid., I 38 ; italics in original. 35 Morrison, Tar Baby, io.

36 Traylor, "The Fabulous World," I 38.

37 M. E. Bradford, "That Other Republic: Romanitas in Southern Literature," Southern Humanties Review: The Classical Tradition in the South: A Special Issue (1977), 4-20.

38 Shields, American Aeneas, xl; italics in original. 
John Smith's Virginia Company." 39 According to Richard Beale Davis, Sandys's dedication of the ${ }_{1} 626$ edition to King Charles I describes the work as "Sprunge from the Stocke of the ancient Romanes, but bred in the Newworld," 40 and the 1632 edition is replete with commentaries that directly connect Ovid's writing with the colonizer's experiences in Virginia. As John Shields observes, the seventeenth-century writer "transforms his translation into something distinctly American when he explains Ovid's text in terms of the American (Virginian) environs." ${ }^{41}$

In Shields's opinion, the fact that Sandys was actually living and working in the new Virginia colony while translating "a major part" of the Latin poem "serves as a compelling and attractive metaphor for what actually was occurring as a result of European intervention in the New World." ${ }^{22}$ The critic also draws attention to (but does not analyse) the fact that Sandys entitled his editions Metamorphosis rather than Metamorphoses; ${ }^{43}$ presumably, through insisting on the singular form, the translator wished to emphasize the notion of Virginia's settlement as a kind of miraculous transformation. Such a myth of origins is indeed "compelling and attractive," $" 44$ but to represent the annexation of the Americas as a magical, natural or divinely ordained process akin to the processes with which Ovid is concerned is to obscure political reality. Tar Baby anticipates Love in both drawing attention to and counteracting such ideologically motivated classicism.

Martin Snyder has observed that many details from the account of the Golden Age in Ovid's Metamorphoses "were echoed in early accounts of America." "The description of "the Ages of Mankind" in that poem immediately follows that of "The Creation," in which "whatever god it was" transformed "Chaos" into a kind of paradise. ${ }^{46}$ By contrast, the first description of the Isle des Chevaliers in Tar Baby - in its account of the way human settlement destroyed the natural environment - comprises a kind of

39 Ibid., 9. As I point out in Transforming America: Toni Morrison and Classical Tradition, examples of Morrison's engagement with the Metamorphoses include a crucial allusion to the Baucis and Philemon myth in Paradise and her reversal of the Pygmalion myth in Sula. In "Lady No Longer Sings the Blues," Madonne Miner does discuss The Bluest Eye's engagement with Ovid's account of Philomena, but to the best of my knowledge she is the only published critic to discuss the Latin author in relation to Morrison; Miner, 85. It is not impossible that Morrison is familiar with George Sandys's I632 Metamorphosis since it was republished by Garland in New York in 1976; at this time Morrison was a New York-based editor at Random House.

40 Richard Beale Davis, George Sandys, Poet-Adventurer: A Study in Anglo-American Culture in the Seventeenth Century (London: Bodley Head, I955), $203 . \quad 41$ Shields, 37.

${ }^{42}$ Ibid., 71. ${ }^{43}$ Ibid., Iо. ${ }^{44}$ Ibid., 71. ${ }^{45}$ Snyder, "The Hero in the Garden," I 48.

46 Ovid, Metamorphoses, trans. A. D. Melville (Oxford: Oxford University Press, I986), I-4. 
creation myth in reverse. Through a series of parodic inversions, the novel undermines the authoritative position of the Ovidian account of human civilization's origins. For example, as part of what Morrison calls "the end of the world," the river on the island "crested, then lost its course, then finally its head. ... It ran every which way ... until exhausted, ill and grieving, it slowed to a stop just twenty leagues short of the sea." 47 This depiction of the waterway's fate exactly reverses the observation in Metamorphoses that the Creator "rivers hemmed in winding banks to flow, / Which ... sometimes ... reach the sea / And... / With new-found freedom beat upon the shores." 48 Similarly, while Ovid's god "bade ... the forest trees / Don their green leaves," 49 in Morrison's novel "the men had gnawed through the daisy trees until, wild-eyed and yelling, they broke in two and hit the ground." Morrison's revision of the classical creation myth unsettles historiographers' use of Ovid's text as the definitive analogy for the European settlers' project. It leaves no doubt that the colonization of the Americas was less a process of miraculous metamorphosis than (to return to Traylor's phrase) one of "a virgin world raped by the machinations of man."

\section{AMERICA AS KORE}

Two notorious rapes in the Metamorphoses are Tereus's of Philomel (to which Shakespeare refers in both The Rape of Lucrece and the "Roman" play, Titus Andronicus), and Pluto's of Proserpina. Several critics have discussed Morrison's engagement with the myths of Philomel and of Proserpina or Kore in depicting the fate of The Bluest Eye's Pecola. ${ }^{51}$ Given that Love shares with Morrison's first novel the thematic concern with rape, it is unsurprising that the author also returns to the Kore paradigm in the most recent work. But while in The Bluest Eye she never mentions her mythological types by name, in Love she makes a crucial punning allusion. May writes to Christine (about the activities of the Congress of Racial Equality) that "CORE is sitting-in in Chicago"; in her ignorance, Christine asks, "Who was she, this

47 Morrison, Tar Baby, 7. $\quad{ }^{48}$ Ovid, 2. $\quad 49$ Ibid., 2. $\quad{ }^{50}$ Morrison, Tar Baby, 8.

${ }^{51}$ See, for example, Demetrakopoulos, "Bleak Beginnings," and Miner, "Lady No Longer Sings the Blues." It is also worth noting that Marrianne Hirsch, in her psychoanalytical reading of Beloved, is "convinced that ... Morrison uses Oedipus and Demeter as intertexts which serve to confront a Western notion of family with the realities of a slave economy"; Marianne Hirsch, The Mother/Daughter Plot: Narrative, Pscyhoanalysis, Feminism (Bloomington and Indianapolis, Indiana University Press, 1989), 201. For a general discussion of the usefulness of the Demeter-Persephone paradigm to recent feminist writers see ibid., I-39 and $197-98$. 
Cora?"52 The way the character turns "core" into "cora" reflects the way the Greek "Kore" becomes the anglicized "Kora," thus intensifying the classical resonances of the sexual violence in the novel. The homophonic wordplay also brings to mind William Carlos Williams's Kora in Hell: Improvisations (1920) - a work by an author whose prose as a whole epitomizes the kind of "male pride" in writing about rape and about the discovery and conquest of America that Morrison sets out to "sabotage" in Love. ${ }^{\mathbf{5 3}}$

The African American writer selects an incriminating quotation from Williams's "Adam" as an epigraph to the third chapter of Playing in the Dark: "But there was a special hell besides / where black women lie waiting for a boy." "54 This suggests both her familiarity with and her antagonism towards her predecessor's work. Love comprises a revisionary perspective on the male author akin to the dialogue that certain passages in the Morrisonian oeuvre establish with Eugene O'Neill or Ezra Pound, and this intertextuality exemplifies the novelist's engagement with "classic" American writers who themselves deploy classical tradition. ${ }^{\mathbf{5 5}}$ Williams's attempt in Kora to

${ }^{52}$ Morrison, Love, 96. Notably, the allusion to Kore occurs in a letter from a mother to her distant daughter (from May to Christine). In addition to alluding to a classical paradigm of rape, Morrison harnesses the fact that the Homeric "Hymn to Demeter" (in Hirsch's description) is "not only the story of intense mother-daughter separation, but also the story of both the mother's and the daughter's reactions and responses"; Hirsch, 35 .

${ }^{53}$ William Carlos Williams, Kora in Hell: Improvisations (1920), reptd. in William Carlos Williams, Imaginations, ed. Webster Schott (New York: New Directions, 1970), 6-82. Morrison uses the word "sabotage" in the radio programme description of her aims in Love that I quote earlier in this article. Start the Week, BBC Radio 4, 8 Dec. 2003. There are of course several "Coras" in African American literature to whom Morrison may be alluding simultaneously. These include the desperately downtrodden but morally courageous eponymous heroine of Langston Hughes's short story, "Cora Unashamed," and the Cora in Jean Toomer's Cane, a "mulatto woman" with whom Kabnis indulges in a night of sexual frolics. Langston Hughes, "Cora Unashamed," in idem, The Ways of White Folks (New York: Alfred A. Knopf, 1969; first published 1934), 3-18; Jean Toomer, Cane (1923), in Henry Louis Gates Jr and Nellie Y. McKay, eds., The Norton Anthology of African American Literature (New York and London: Norton, 1997), 1089-1 169. Neither of these figures illuminate Love's thematic concern with rape, however, in the way that the Greek Kore and Williams's Kora in Hell do.

54 Quoted in Toni Morrison, Playing in the Dark: Whiteness and the Literary Imagination (London: Picador, I993; first published I992), 6I.

55 The blatant "Africanism" of certain passages in Williams's work - such as his "Advent of the Slaves" chapter in In the American Grain-makes him a prime target for Morrison; Williams, In the American Grain, 208-1 I. In my Transforming America: Toni Morrison and Classical Tradition I explore the author's revisionary dialogue with O'Neill and Pound. I argue, for example, that, through the portrait of Cosey, Morrison may well be signifying on Mourning Becomes Electra, in which "a large portrait of Ezra Mannon himself" hangs alongside paintings of Washington, Hamilton and Marshall in the patriarchal study. The surviving cast live in the shadow of Mannon's life and portrait as the characters in Love do in that of Cosey; Eugene O'Neill, Mourning Becomes Electra (London: Jonathan Cape, 
reconcile the apparently irreconcilable ancient world and modern America - "Herakles rowing boats on Berry's Creek! Zeus is a country doctor without a taste for coin-jingling" - would of course be of interest to Morrison. ${ }^{\mathbf{5 6}}$ And to some extent he and she share a desire to undermine the conservative role that the dominant culture has demanded of classicism. "Of course history is an attempt to make the past seem stable and of course it's all a lie," declares Williams. "Nero must mean Nero or the game's up." "57 But the unifying premise of Kora in Hell-an association between the raped goddess and the poetic imagination, America and even Williams himself - encapsulates much that Morrison's most recent novel sets out to counter.

As in In the American Grain, rape is the structuring motif of Kora, and in both works it is somehow at once necessary and glorious. The Improvisations are punctuated by allusions to sexual violence and its victims that are cheerfully glib in tone: "Oh quarrel whether 'twas Pope Clement raped Persephone or-did the devil wear a mitre in that year?," or, "Think of some lady better than Rackham draws them: ... some Lucretia out of the Vatican turned Carmelite."58 And of particular relevance to Love and its group assault of Pretty-Fay is the fact that Williams writes excitedly about a gang-rape:

The ground lifts and out sally the heroes of Sophokles, of Aeschylus. They go seeping down into our hearts, ... down - to a saloon back of the rail-road where they have that girl, you know, the one that should have been Venus by the lust that's in her. They've got her down there among the railroad men. ... Up to jail - or call it down to Limbo - the Chief of Police our Pluto. ... When they came to question the girl before the local judge it was discovered that there were seventeen men more or less involved, so that there was nothing to do but to declare the child a common bastard and send the girl about her business. ${ }^{59}$

In this passage, the abrupt shift from the formal tenor of the first two sentences to the colloquialism beginning with "to a saloon back of the railroad" suggests that the author finds something distinctively "American," something that helps him find his idiom, about the gang-rape. The episode comprises an extreme example of the "rape scene" that "seems to have no shame" about which Morrison complained on Radio 4 and it epitomizes the

I 966; first published 1932), 5 I. Corrie's allusion to the Cadmus myth in Song of Solomon, meanwhile, revises Pound's deployment of the same myth in the first of his "Adams" Cantos; Ezra Pound, Canto 62, in idem, Selected Poems 1908-69 (London: Faber, 1977; first published 1975), I 59-62. ${ }^{56}$ Williams, Kora in Hell, 60. ${ }^{57}$ Ibid., 4I. ${ }^{58}$ Ibid., 41, 42.

59 Ibid., 6o-6r; original emphasis. 
fusion of classicism, Americanism and sexual violence that is parodied in Love. ${ }^{60}$

The representation of the colonization of America as a sexual act - a tradition within which Morrison ironically inscribes Bill Cosey - is more explicit in In the American Grain than in Kora in Hell. In his chapter on Christopher Columbus, Williams describes the discovered land as a "ravished" flower, while he later depicts Walter Raleigh "plunging his lust into the body of a new world." 61 The section on De Soto comprises the most extreme depiction of the land as female; here Florida is personified as an alluring seductress, "She," who ensnares the Spaniards in her "caresses" and the "onwash of [her] passion." 62 Is it just a coincidence that in Love, where L refers explicitly to the conquering Spaniards naming part of the shore "Sucra," the car that the school principal abandons at the Settlement is a "DeSoto"? ${ }^{63}$

Williams sums up the organizing principle of Grain in the chapter on Edgar Allan Poe, where (in an ambitious conflation of a literary conqueror with a literal one) he asserts, "One is forced on the conception of the New World as a woman. Poe was a new De Soto." ${ }^{, 44}$ Both the passive construct "one is forced" and the later claim that Poe made an "immaculate attack" on the body of America typify the way the dominant culture glorifies the notion of American settlement as rape while at the same time insisting that colonization was a guiltless, impersonal process of metamorphosis rather than an outrageous violation. ${ }^{65}$ This doubleness reappears in Love in the apparent contradiction between Romen's heroic conception of the attack on Pretty-Fay (and of sexual predatoriness in general) and Cosey's insistence on the innocence of his behaviour towards Heed.

In addition to their widespread celebration of rape, Williams's prose works are punctuated by an interest in Cosey-and-Heed-style relationships. "Marry in middle life and take the young thing home," advocates Kora in Hell, while The Great American Novel (1923) mocks a community's moral outrage: "What do you think! He has left his wife, and a child in the high school has been ill a week, weeping her eyes out and murmuring his name. Is it not terrible? ${ }^{, 66}$

\footnotetext{
60 Start the Week, BBC Radio 4, 8 Dec. 2003. ${ }^{61}$ Williams, In the American Grain, 7, 59.

${ }^{62}$ Ibid., 50, 53.
}

${ }^{64}$ Williams, In the American Grain, 220. Both Edgar Allan Poe's real-life marriage to the thirteen-year old Virginia Clemm and many of his short stories resonate in the plot and the gothic melodrama of Love. Morrison explicitly takes Poe to task for his "Africanism" in Playing in the Dark, 3 I-54. $\quad{ }^{65}$ Williams, In the American Grain, 221.

${ }^{66}$ Williams, Kora in Hell, 39; William Carlos Williams, The Great American Novel (1923), in idem, Imaginations, I $58-227$, I 80. 
And a final affinity between Love and Kora is the fact that the author of the second work here declares his preference for the Romans over the Greeks. "I like better the Greeks setting their back to Athens," Williams writes. "The ferment was always richer in Rome, the dispersive explosion was always nearer, the influence carried further and remained hot longer. ${ }^{, 67} \mathrm{His}$ implication is that Rome has had greater influence on America than has Greece, and he thereby subscribes fully to the belief in an analogy between his country and the ancient imperial power that Morrison takes to task through the Romanness of Romen and his world.

\section{“THE REAL ROMEN”: NEW POTENTIAL IN ANCIENT TRADITION}

Despite their flawedness, Morrison ultimately makes both Cosey and the "Gibbons boy" a counterpoint to the tradition in which Williams writes by both associating and disassociating her characters from that genealogy. ${ }^{68}$ In refusing to join in the gang-rape, Romen (in spite of himself) sets himself apart from the prototypical classic and American hero. On the verge of participating, he believes he is about to fulfil the ideal of glorious manhood, and in rescuing the girl he feels in his shame that "it was the real Romen who had sabotaged the newly chiseled, dangerous one." 69 Through sadistic sex with June he thinks that he has redeemed himself from his earlier humiliation, but at his moment of anagnorisis that precedes his rescuing of Christine and Heed, he realizes that "the old Romen, the sniveling one who couldn't help untying shoelaces from an unwilling girl's wrists, was hipper than the one who couldn't help flinging a girl around an attic."70 Thus the real Romen does indeed "sabotage" the all-conquering, sexually predatory American archetype, and Morrison is successful in her aim to "sabotage" the "male pride" in conventional representations of rape. ${ }^{71}$

Even Bill Cosey himself finally functions both to critique and transform the paradigm of heroic sexual violence. For while he is unquestionably a morally problematic figure, in that (among other transgressions) he fondles the unmarried Heed's breast and masturbates in Christine's bedroom, Morrison implies that he does not in fact rape Heed. In old age, his widow recalls with pleasure that on her wedding night there had been

\footnotetext{
67 Williams, Kora in Hell, i 2. $\quad{ }^{68}$ Morrison, Love, 24. $\quad{ }^{69}$ Ibid., 49. $\quad{ }^{70}$ Ibid., i95.

71 Start the Week, BBC Radio 4, 8 Dec. 2003.
} 
"No penetration. No blood," and that instead Cosey had lovingly bathed her. ${ }^{72}$ So, while in Paradise the author allows the possibility of a better future by giving the men of Ruby the chance to redeem themselves, in Love she achieves the same effect by finally saving her protagonists from committing the classic, classically associated crimes. And implicit in this rescue-job is a sense of the transformed possibilities inherent in classicism itself.

Morrison's exposure of the use to which the dominant culture has put the ancient world is accompanied in all her novels by a determination to make that world serve new ends. This is exemplified in Love by a crucial second meaning implicit in the CORE/Kore pun. By associating the Congress of Racial Equality with Kore - "CORE is sitting-in in Chicago (who was she, this Cora?)" - Morrison enlists classical tradition to comment on what Michele Wallace has termed the "macho" elements of the civil rights movement and on the problematic implications of those elements for black women. ${ }^{73}$ Implying that one of the movement's defining organizations had affinities with the violated goddess of Greek myth specifically critiques the tendency to reinscribe mainstream oppression of black women exemplified by Stokely Carmichael's notorious assertion that the "only position of women in SNCC is prone" - that Wallace documents. ${ }^{74}$ The allusion suggests that the movement itself has become a corrupted, violated cause. In both its method and its effect it recalls the simile in Song of Solomon in which Corrie wonders whether the menfolk in her life (that is, the members of the Seven Days, her father and her brother) always "rose like giants from dragon's teeth and, while the women slept, clustered in their kitchens."75 This feminist revision of the myths of Cadmus and Jason anticipates the similar redeployment of the Kore archetype in Love. Both allusions epitomize Morrison's politically strategic application of well-worn classical references to unconventional contexts.

Like its predecessors, then, Love both destabilizes and reinvigorates classical tradition. The positioning of Romen and Cosey at once within and without the tradition of glorious rape - one of America's most entrenched self-defining paradigms - typifies the ambivalence towards both classical tradition and "classic" American literature that characterizes the author's work as a whole. Morrison's double take on the classics is what enables

72 Morrison, Love, 77.

73 Ibid., 96. For Wallace's discussion of the misogyny of the Black Power movement see Michele Wallace, Black Macho and the Myth of the Superwoman (London and New York: Verso, 1990; first published 1978), especially 6-7, I 3, 34-38. $\quad{ }^{74}$ Wallace, 7.

75 Toni Morrison, Song of Solomon (London: Picador, I989; first published 1977), 203. 
her to condemn the past and its narratives without denying the potential of the future. And it is a crucial means by which she fulfils in her own fiction the aims of her critical practice: "to open as much space for discovery, intellectual adventure, and close exploration as did the original charting of the New World - without the mandate for conquest." $" 76$

${ }^{76}$ Morrison, Playing in the Dark, 3. 